УДК 338.24

DOI https://doi.org/10.32849/2663-5313/2020.7.22

Людмила Асанова, аспірант кафедри публічного управління та адміністрування Національної академії внутрішніх справ

\title{
ОРГАНІЗАЦЙНО-ПРАВОВИЙ АСПЕКТ УПРОВАДЖЕННЯ ЕЛЕКТРОННОГО ДОКУМЕНТООБІГУ У ПРАВООХОРОННИХ ОРГАНАХ УКРАЇНИ
}

Розвиток суспільства відбивається на соціально-економічних процесах, що не можливі без проиесу управління, який є важливим чинником для забезпечення якісного функиіонування державної влади та органів місиевого самоврядування. Незважсаючи на велику кількість прачь, присвячених дослідженню різних аспектів способів документування інформаиї̈, ї̈ форм, видів, необхідно констатувати, що у юридичній літературі так і не сформовано усталеної, повноиінної дефінічії електронного документування. Метою статті є огляд й упорядкування сформованих типів організації документообігу в правоохоронних органах, яка впливає на якість та ефективність роботи цих установ. Як результат, подальше вироблення иілісного уявлення про поняття документообігу та документування, а також виклад власного бачення оптимальної методологічної основи для визначення способів подальшого розвитку иієі сфери шляхом розроблення наукових рекомендаиій шодо вдосконалення системи інформачійного забезпечення правоохоронних органів та переходу їх на електронний документообіг. Встановлено, що у сучасний період документ розглядається як один з інструментів пізнання дійсності, що відображає інформацію, яка зберігається $і$ передається у часі і просторі, реалізуючи прочес управління шляхом створення і використання різноманітних документів, тому вивчення діловодства як складної управлінської діяльності стає надзвичайно актуальним. Оптимальною методологічною основою для визначення поняття «електронний документообіз» $є$ діалектична теорія пізнання, загальнонаукові методи спостереження, опису, порівняння, які допоможуть впровадити новітні технології документування інформачії. Визначено, що під інформачійно-аналітичним забезпеченням розуміється комплекс заходів щодо збирання, отримання, зберігання, користування, обробки та накопичення інформаиії з подальшим ї̈ аналізом з метою прогнозування або підведення підсумків діяльності і корегування залежно від цього подальших управлінських рішень. Управлінська діяльність реалізовується на приниипах верховенства права, дотримання прав і свобод людини, законності, відкритості та прозорості, політичної нейтральності, взаємодї̈ з населенням на засадах партнерства та безперервності.

Ключові слова: поняття інформації, документ, електронний документообіг, документування, управління, організаційно-правовий аспект, провадження.

Постановка проблеми. Розвиток суспільства зумовлює зміни у соціальному, політичному, економічному, духовному, навіть фізіологічному процесах і вимагає пошуку відповідей на питання: які фактори, форми та динаміка необхідні для подальшого його ефективного існування.

Соціально-економічні процеси, які відбуваються у сучасному суспільстві, не можливі без управління, яке є важливим чинником для забезпечення якісного функціонування державної влади та органів місцевого самоврядування. Документування і його організація впливає на якість та ефективність роботи будь-якої установи. За допомогою документа інформація зберігається і передається у часі і просторі, а тому з цієї точки зору документи можуть розглядатися як один 3 інструментів пізнання дійсності. Сучасний діловий світ важко собі уявити без потужних потоків інформації, що циркулює у різних напрямах й оформлена найчастіше документально. Процес управління реалізується шляхом створення і використання різноманітних документів [4, с. 313], тому вивчення діловодства як складної управлінської діяльності стає надзвичайно актуальним.

Огляд останніх досліджень і публікацій. Окремі аспекти окресленої проблематики фрагментарно розглядалися у працях В. Бездрабко, А. Діденка, С. Дубової, О. Загорецької, Т. Іванової, О. Карпенко, М. Матліної, С. Кулешова, О. Матвієнко, А. Ніколашина, I. Петрової, Ю. Палехи та інших. Питанням 
історичного досвіду та правового регулювання документообігу в цілому приділялася увага у працях В. Савицького, В. Сокуренка М. Слободяника, Н. Кушнаренка, В. Бездрабка, С. Кулешова, Ю. Сурмини. На дослідженні збереження електронних документів на підприємстві акцентують увагу М. Ларін, М. Бобильов, Ю. Вітін, В. Тихонов, І. Юшин, Г. Асеев, О. Матвієнко, В. Боркус.

Формулювання завдання дослідження. Нині Президентом України проголошено вектор «діджиталізації», що дасть змогу скоротити документообіг та впровадити єдиний порядок документування, організації роботи з документами, побудови єдиної інформаційно-довідкової системи контролю їх використання.

Робота саме правоохоронних органів відповідно до українського процесуального законодавства організована та побудована на опрацюванні і використанні паперових документів із так званим «живим» підписом, 3 необхідністю їх багаторазового копіювання, доставляння до різних структурних підрозділів, проведення спеціальних нарад, необхідністю погоджень відповідно до ієрархічної субординації та засвідчування належним чином цих копій. Усі ці процедури та процеси затратні щодо персоналу, часу, фінансів і тому малоефективні щодо прийняття управлінських рішень, спрямованих на виконання установою тих безпосередніх функцій, які забезпечують її діяльність. Водночас не варто забувати про інші проблеми, пов'язані із витратами часу на тривалі пошуки необхідної інформації або документа за запитом, а також облаштуванням відповідних місць для їх зберігання.

3 огляду на це, перед вибором програмного продукту для правоохоронного органу необхідно з'ясувати, на яку організаційну структуру установи розрахована система (кілька структурних підрозділів чи один), визначити набір функціональних вимог до системи, можливість інтеграції ï з іншими програмними продуктами установи, врахувати обсяг документообігу, кількість користувачів тощо.

Визначені технічні характеристики програмного продукту мають відповідати основній своій меті і впроваджуватися в установах, де чітко врегульовані, достатньо описан діловодні процеси. Необхідно розробити інструкції з організації електронного документообігу 3 урахуванням особливостей діяльності установи, вимог законодавства, проводити навчання персоналу. Під час опису електронного документообігу установи у своїх інструкціях не варто нехтувати деталізацією процесів, конкретизацією ролей та визначенням прав та рівнів доступу до інформації, яка міститься в документах, термінів і місця ï зберігання, а також способів знищення

Виклад основного матеріалу Аналізуючи правові засади документальної діяльності правоохоронних органів, слід зазначити, що деякі з них до сьогодні здійснюють діловодство згідно з локальними Інструкціями 3 діловодства, які написано було на основі тих типових, що втратили чинність. Покладаючись лише на інституційну пам'ять установи, не поспішають виписувати новітні правила, окремі акти, які б урегульовували документообіг саме правоохоронних органів, що, безперечно, є невід'ємною частиною документообігу загальнодержавного рівня.

Відповідно до Типової інструкції з документування управлінської інформації в електронній формі та організації роботи з електронними документами в діловодстві, електронного міжвідомчого обміну, затвердженої Постановою Кабінету Міністрів України від 17.01.2018 р. № 55 документообіг установ має здійснюватися в електронному вигляді. А положення Типової інструкції з діловодства в міністерствах, інших центральних та місцевих органах виконавчої влади застосовуються лише до паперових документів і лише у разі наявності визначених законом підстав, які визнані обгрунтованими для створення та/ або опрацювання установами документів у паперовій формі.

Для забезпечення максимальної ефективності, прозорості та оперативності прийняття управлінських рішень необхідна оптимізація та автоматизація процесів діловодства. Інформаційне забезпечення полягає у своєчасному наданні достовірних інформаційних ресурсів у розпорядження особи, яка розробляє або приймає управлінське рішення. Документообіг порівняно $з$ діловодством є ширшим поняттям, що, окрім підготовки документів та роботи 3 ними, означає ще й виконання документами функції інформаційного забезпечення управлінських рішень.

Організацію діловодства пропонує С. Сельченкова у своєму практичному посібнику «Діловодство» [8] умовно поділити таким чином:

- документування (фіксування інформації, складання та оформлення документів);

- робота 3 документами (одержаннявідправлення, опрацювання, реєстрація, контроль за виконанням, облік, зберігання, використання, підготовка до передавання на архівне зберігання, знищення). 
Таким чином, діловодство має охоплювати всі процеси з моменту створення документа до його знищення чи передавання на архівне зберігання.

Щодо документування, то паперові документи, які не містять інформацію з обмеженим доступом, не розкривають зміст кримінального провадження, не містять персональні дані та іншу охоронювану законом інформацію після отримання службою діловодства за наявності технічного, програмного забезпечення та централізованої форми ведення діловодства мають скануватися в систему електронного документообігу. Це надаватиме змогу фіксувати інформацію в єдиній системі установи. Впровадження електронного документообігу головним чином спрямоване не на вилучення з обігу паперових документів, а на створення достовірної бази даних та ефективного середовища управління й функціонування установи. Щодо роботи з документами слід зазначити, що наявні чинники психологічної готовності керівників та службовців до використання електронних аналогів «живого» підпису на документі, що значно прискорює одержаннявідправлення, опрацювання, реєстрацію, контроль за виконанням, облік, зберігання, використання, а також підготовку до передавання на архівне зберігання відповідно до номенклатури справ установи, яка теж має складатися в електронному вигляді.

Разом із тим є проблема доступу та надання інформації установам, організаціям, правоохоронним органам та впровадження електронного документообігу, яка розглядається у книзі М. Демкова та М. Фігеля [9]. Автори розглядають питання правового забезпечення інформаційної безпеки у разі впровадження електронного документообігу в системи електронного уряду в Україні та розробляють власну концепцію електронного урядування.

Упровадження електронного документообігу в інформаційно-документаційні процеси постійно розвивається в різних країнах світу. Як слушно зазначає К. Бєляков, інформаційне суспільство не є альтернативним для різних суспільно-економічних систем, як не існує альтернативи і для індустріального суспільства, у межах якого співіснували капіталізм та соціалізм. Однак комплекс суспільно-державних підсистем, насамперед соціально-політичних та економічних, а також світогляд і філософські погляди, що сформувалися під їхнім впливом, можуть істотно впливати на терміни переходу в нову стадію цивілізації [10].

Цілком зрозуміло, що електронний документообіг є основою для багатьох напрямів діяльності установ, організацій, органів державної влади, правоохоронних органів та впровадження технології документування, документообігу, однією з основних функцій яких є надання адміністративних послуг у тому числі за допомогою інтернет-технологій.

До найбільш ефективних напрямів використання електронних технологій та електронного документообігу в традиційному діловодстві належить підготовка документів із використанням електронних технологій, що здійснюється за правилами і 3 використанням форм і бланків уніфікованих документів. За потреби тексти виводяться на папір і набувають відповідно до чинних правил форми документів 3 визначеними обов'язковими реквізитами; електронна передача інформації використовується для прискорення іiї доставки споживачам 3 подальшою можливістю виведення документів на папір; актуальним завданням $\epsilon$ визначення місця факсимільної передачі документа в системі традиційного діловодства; електронна реєстрація надходження документів у систему передбачає включення в єдину інформаційну систему всіх документів, які створюються в організації або надходять до неї у будь-якій формі на основі єдиних правил реєстрації. До того ж на реєстраційному масиві грунтується облік, пошук, контроль виконання документів без створення інших реєстраційних форм [3].

Законом України від 22.05.2003 № 851IV «Про електронні документи та електронний документообіг» [12] визначено поняття електронного документа та електронного документообігу та закріплюється визнання юридичної сили електронного документа, визначаються права, обов'язки і відповідальність суб'єктів електронного документообігу. Для запобігання проблемі законодавчо врегульованої ідентифікації широкого використання електронних документів в Україні був прийнятий Закон України від 22.05.2003 № 852-IV «Про електронний цифровий підпис» [14].

Для запобігання проблемі доставляння та отримання документів у процесі впровадження електронного документообігу у разі постійних структурних змін в установі, або перебування працівників у відпустці, відрядженні, на лікарняному, або у разі інших кадрових перестановок для формалізації виробничих процесів необхідно впровадити автоматизовану кадрову інформаційно-аналітичну систему та забезпечити інтеграцію 3 нею системи електронного документообігу для здійснення автоматичної переадресації конкретного документа до потрібного виконавця, оскільки наявність таких рухів в уста- 
нові може затримувати передачу масивів інформації в електронному вигляді. А впроваджена система електронного документообігу здатна суттєво спростити та прискорити реалізацію виконання доручених керівництвом установи завдань працівникам.

Водночас під час впровадження електронного документообігу в діяльність правоохоронних органів необхідно враховувати високі вимоги до програмного продукту щодо забезпечення захисту та збереження цілісності даних, адресність та обмеження доступу. Мають бути чітко виписані ролі, рівні доступу та режими опрацювання документів, що затверджується керівником установи. На жаль, рівень документування та електронного документообігу в Україні не відповідає міжнародним стандартам. Не всі системи електронного документообігу мають експертні висновки за результатами державної експертизи у сфері криптографічного захисту інформації та в деяких випадках не відповідають чинному законодавству.

Окремі правоохоронні органи лише намагаються створити відомчі системи електронного документообігу, на відміну від яких Національне антикорупційне бюро України має систему електронного документообігу й активно використовує її, зокрема, в управлінських цілях та є учасником Системи електронної взаємодії органів виконавчої влади (далі - СЕВ ОВВ)

Так, наприклад, у Національному антикорупційному бюро України процеси узгодження та підписання проєктів листів, нормативно-розпорядчих документів, доповідних записок здебільшого вже відбуваються із застосуванням електронного цифрового підпису. Переважно внутрішні документи (службові записки, доповідні записки, заяви) реєструються автоматично після підписання іх у системі електронного документообігу підписувачем, що прискорює прийняття управлінських рішень. Оскільки під час вирішення працівниками поставлених завдань, що стосуються дотримання процедур та прийняття процесуальних рішень у встановлені законом короткі строки, за наявності паперового документообігу служба діловодства могла уповільнювати цей процес у зв'язку з проходженням документа спочатку на реєстрацію, потім на резолюцію і лише після підписання резолюції керівником - на видачу до зазначеного виконавця під підпис у картці. Завдяки опрацюванню документів в електронному вигляді і підписанню їх електронним цифровим підписом із процесу підготовки документів та їх підписання з подальшою автоматичною реєстрацією було виключено Відділ документообігу, що значно скоротило шлях проходження документів і $є$ корисним для всіх учасників цього процесу.

Проблема переходу державних правоохоронних органів до електронного документообігу - це процес поступовий, але безповоротний. У суспільстві можуть відбуватися різні зміни, на виникнення яких саме правоохоронні органи, на мою думку, мають бути готові першими відреагувати.

Саме від правоохоронних органів та інших державних органів суспільство очікує взірцевого шаблону, високих стандартів і швидкого реагування для прийняття управлінських рішень щодо загроз, які постають перед суспільством.

Як зазначає В. Сокуренко у підручнику «Управління органами Національної поліції України» [1], процес управління без інформації стає неможливим, її відсутність не дає можливості сформулювати завдання та мету управління, провести оцінку ситуації, виділити проблеми, передбачити розвиток подій, підготувати управлінські рішення і проконтролювати їх виконання. Сфера забезпечення правопорядку є надзвичайно мінливою, комплексною та потребує систематичного вдосконалення, взаємодії правоохоронних органів, що можливе лише за умови належного рівня інформаційного забезпечення.

Інформаційно-аналітична діяльність - це сукупність дій на основі концепцій, методів, засобів, нормативно-методичних матеріалів для збору, накопичення, обробки та аналізу даних з метою обгрунтування та прийняття рішень[2]. Прийняття рішень - це науковий напрям, завданням якого є синтез раціональних схем вибору альтернатив і оцінювання їх якостей. Завдання його в тому, щоб із багатьох конкуруючих стратегій розв'язання певної проблеми на основі аналізу умов і наслідків їх реалізації вибрати кращу (оптимальну). Істотним доповненням до останньої тези $є$ те, що під умовами розуміється не деяка картина «натепер», що застигла, але й ті умови, які можуть скластися за час реалізації стратегії [3].

У перекладі з латинської мови «інформація» (information) - це роз'яснення, виклад. Поняття інформації неодноразово змінювалось, його межі то розширювалися, то звужувалися. Спочатку під цим словом розуміли «уявлення», «поняття», потім - «відомості», «передачу повідомлень».

Вікіпедія говорить, що однозначного визначення інформації не існує, і пов'язане це 3 тим, що цей термін використовується в багатьох областях людської діяльності, тобто є багатогранним. Спеціалістів із теорії 
зв'язку цікавить насамперед передача інформації від джерела до отримувача без спотворень, філософа - розуміння змісту, фахівця з комп'ютерних технологій - процеси запису, зчитування, зберігання й обробки, диктора на радіо - доведення повідомлення до відома широкого кола слухачів. Залежно від галузі використання термін «інформація» набув багато різних визначень [6].

Усі зазначені терміни є різними гранями єдиного складного природного явища, яким $€$ інформаційна реальність.

Існують також й інші, переважно несумісні між собою визначення поняття «інформація». Але відповідно до вільної енциклопедії практично всі погляди на сутність інформації групуються навколо двох концепцій - атрибутивної та функціональної. Атрибутивна концепція інформації наголошує на тому, що інформація є атрибутом (невід'ємною властивістю) об'єктів. Функціонально-кібернетична концепція вважає, що головним в інформації є та функція, яку вона виконує. Особливо цікавою є функція, яку відіграє інформація, закладена, наприклад, у ДНК в розвитку біологічних організмів та інших систем, в яких можлива самоорганізація.

У зв'язку з цим систему документообігу установи можна порівняти 3 кровоносною системою живого організму, що забезпечує вчасну доставку необхідного до компетентних органів.

Якщо ми говоримо про інформацію як про юридичний термін, то формою його вираження буде законодавча норма, що закріплює термін «інформація». Закон України «Про інформацію» визначає інформацію як будь-які відомості та/або дані, які можуть бути збережені на матеріальних носіях або відображені в електронному вигляді [5]. Така дефініція має певні недоліки. По-перше, акцентується увага на тому, що обов'язковою умовою для даних та відомостей є можливість їх закріплення на матеріальних носіях (на будь-якому матеріальному об'єкті чи середовищі, що може протягом певного терміну зберігати, тобто нести у своїй структурі занесену у/на нього інформацію, наприклад на камені, дереві, папері, металі, пластику, магнітних матеріалах, напівпровідниках тощо) [6] або відображення даних в електронній формі, тобто фіксація на електронному носії з використанням засобів обчислювальної техніки і можливістю передачі за допомогою електрозв'язку. Але якщо проаналізувати поняття «дані», стане зрозумілим, що дані передбачають їх автоматичну обробку електронно-обчислювальними пристроями, а тому є очевидною їхня власти- вість бути відображеними в електронному вигляді. По-друге, враховуючи, що термін закріплює під інформацією лише «відомості та/або дані, які можуть бути збережені на матеріальних носіях або відображені в електронному вигляді», може ускладнитися його правозастосування у цивільно-правових відносинах для прийняття оптимальних рішень.

Особистими немайновими благами, які охороняються цивільним законодавством, є: здоров'я, життя; честь, гідність і ділова репутація; ім'я (найменування); авторство; свобода літературної, художньої, наукової і технічної творчості, а також інші блага, які охороняються цивільним законодавством.

Інформаційно-аналітичне забезпечення процесу управління здійснюється на основі інформації, яка $є$ нематеріальним благом (глава 15 Цивільного кодексу України), і не зводиться до матеріального (фізичного) об'єкта, на якому вона зафіксована, або до відображення її в електронному вигляді.

У сучасних умовах роль Інформаційноаналітичного забезпечення управління постійно зростає.

В органах поліції процес інформаційноаналітичного забезпечення у системі управління будь-якого механізму - виробництво спеціально підготовленими фахівцями на підставі наявних інформаційних одиниць і складних розумових процесів нового знання щодо явища або події, що вивчається. Інформаційно-аналітичне забезпечення - це процес створення оптимальних умов задля задоволення інформаційних потреб та реалізації посадових обов'язків органів державної влади на основі формування та використання інформаційних ресурсів. Метою інформаційно-аналітичного забезпечення державних органів виконавчої влади є створення умов для прийняття ефективних державних управлінських рішень [14].

Під інформаційно-аналітичним забезпеченням розуміється комплекс заходів щодо збирання, отримання, зберігання, користування, обробки та накопичення інформації 3 подальшим її аналізом з метою прогнозування або підведення підсумків діяльності і корегування залежно від цього подальших управлінських рішень. Управлінська діяльність реалізовується на принципах верховенства права, дотримання прав і свобод людини, законності, відкритості та прозорості, політичної нейтральності, взаємодії з населенням на засадах партнерства та безперервності.

При цьому залишається невирішеною проблема доступу та надання інформації установам, організаціям, правоохоронним органам під час впровадження електро- 
нного документообігу. У книзі М. Демкова та М. Фігеля [9] автори розглядають питання правового забезпечення інформаційної безпеки під час впровадження електронного документообігу в системи електронного уряду в Україні та розробляють власну концепцію електронного урядування.

\section{Висновки}

У зв'язку з викладеним вище доцільно здійснити комплексне дослідження організаційно-правових засад документообігу як Національного антикорупційному бюро України, так й інших правоохоронних органів, що дасть змогу обгрунтувати та сформулювати низку положень, висновків і пропозицій, розробити концепцію документообігу, яка дозволятиме працівникам правоохоронних органів приймати управлінські рішення та вирішувати поставлені завдання у надзвичайно складних умовах роботи або дистанційно. 3 розвитком інформаційного суспільства та електронних комунікацій, насамперед Інтернету, зростає актуальність застосування електронних технологій опрацювання документів і поступової заміни паперових форм на електронні. Доступність є ключем до застосування i розвитку електронних документів у правоохоронних органах. Це дозволить запровадити та перейти на електронні документи з використанням шаблонів, стандартів, запровадити електронні провадження, що зробить процедури та процеси прозорішими, а також істотно підвищить ефективність праці та якість документів, що готуються у правоохоронних органах.

\section{Список використаних джерел:}

1. Управління органами Національної поліції України : підручник / О. М. Бандурка, О. І. Безпалова та ін. ; за заг. ред. д-ра юрид. наук, доц. В. В. Сокуренка. Харківський національний університет внутрішніх справ, 2017. 580 c.
2. Сурмин Ю. П. Теория систем и системный анализ : учебное пособие. Київ: МАУП, 2003. C. 242.

3. Конотопов П.Ю. Аналитика: методология, технология и организация информационно-аналитической работы. Москва: РУСАКИ, 2004. C. 410.

4. Савицький В.Т. Документ як базове поняття документаційного забезпечення управління. Університетські наукові записки. 2005. № 4 (16). C. 313-318.

5. Про інформацію : Закон України від 02.10.1992 № 2657-XII. Відомості Верховної Ради України. 1992. № 48. Ст. 650.

6. Носитель информации. URL: http:// ru.wikipedia.org/wiki/Электронный_носитель_ информации (дата звернення: 21.06.2020).

7. Цивільний кодекс України. Відомості Верховної Ради Украӥни. 2003. №№ 40-44. Ст. 356. URL:https://zakon.rada.gov. ua/laws/show/435-15 (дата звернення: 21.06.2020).

8. Сельченкова С.В. Діловодство : практичний посібник. Київ: Інкунабула, 2009, 480 с.

9. Доступ до інформації та електронне урядування / авт.-упор. М.С. Демков, М.В. Фігель. Київ: Факт, 2004. 343 c.

10. Бєляков K.I. Інформатизація в Україні: проблеми організаційного, правового та наукового забезпечення : монографія. Київ: КВІЦ, 2008. $576 \mathrm{c}$.

11. Матвієнко О.В., Цивін М.Н. Основи організації електронного документообігу : навчальний посібник для студентів ВНЗ. Київ: Центр учбової літератури, 2008. 112 c.

12. Про електронні документи та електронний документообіг : Закон України від 22.05.2003 № 851-IV. Відомості Верховної Ради України. 2003. № 36. С. 275.

13. Про електронний цифровий підпис : Закон України від 22.05.2003 № 852-IV. Відомості Верховної Ради Украйни. 2003. № 36. С. 276.

14. Коваль Р.А. Інформаційно-аналітичне забезпечення діяльності органів влади : автореф. дис. ... канд. наук з держ. управ.: 25.00.02. Запоріжжя, 2008. С. 8.

Liudmyla Asanova. Organizational and legal aspect of implementation of electronic workflow in law enforcement authorities of Ukraine

The development of society is reflected in the socio-economic processes that are not possible without the governance process, which is an important factor in ensuring the proper functioning of public authorities and local governments. Despite the large number of works devoted to the study of various aspects of ways of documenting information, its forms, types, it should be noted that the legal literature has not formed a wellestablished, full definition of electronic documentation. The purpose of the article is to review and streamline the existing types of document management in law enforcement agencies, which affects the quality and efficiency of these institutions. As a result, further development of a holistic view of the concept of document management and documentation, as well as setting out their own vision of the optimal methodological basis for determining ways to further develop this area by developing scientific recommendations for improving law enforcement information system and their transition to electronic document management. It is established that in the modern period the document is considered as one of the tools of knowledge of reality, reflecting information stored and transmitted in time and space, implementing the management process by creating and using various documents, so the study of of fice work as a complex management activity becomes extremely relevant. The optimal methodological basis for defining the concept of electronic document management is 
the dialectical theory of cognition, general scientific methods of observation, description, comparison, which will help to implement the latest technologies for documenting information. It is determined that informationanalytical support means a set of measures for collecting, receiving, storing, using, processing and accumulating information with its subsequent analysis in order to forecast or summarize the activities and adjust further management decisions. Management activities are implemented on the principles of the rule of law, respect for human rights and freedoms, legality, openness and transparency, political neutrality, interaction with the population on the basis of partnership and continuity.

Key words: concept of information, document, electronic document circulation, documentation, management, organizational and legal aspect, proceedings. 